\title{
Improvement of fire danger rating and vegetation fire behaviour prediction on protected areas
}

\author{
Aleksandra Volokitina ${ }^{1, *}$, Dina Nazimova ${ }^{1}$, Tatiana Sofronova ${ }^{2}$, and Mikhail Korets ${ }^{1}$ \\ ${ }^{1}$ Sukachev Institute of Forest SB RAS, ul. Akademgorodok, 50/28, 660036 Krasnoyarsk, Russia \\ ${ }^{2}$ Astafiev Krasnoyarsk State Pedagogical University, str. A. Lebedevoy, 89, 660049 Krasnoyarsk, \\ Russia
}

\begin{abstract}
Protected areas (PAs) are established to conserve biological diversity, to maintain nature complexes and objects in their natural condition. Strict nature reserves prevail in Russia by their total area. The whole nature complex is forever extracted from economic use in nature reserves. Here it is prohibited to pursue any activity which might disturb or damage the nature complexes. Even under the existing strict protection from anthropogenic ignition sources, vegetation fires do occur on their territory. Besides, lightnings - these natural ignition sources - are impossible to exclude. Since large destructive fires are impermissible in nature reserves, the later especially need vegetation fire behavior prediction for fire management. Fire behavior prediction includes fire spread rate, development (from surface fire into crown or ground one) and fire effects. All this is necessary for taking optimal decisions on how to control each occurring fire and how to suppress it. The Sukachev Institute of Forest SB RAS has developed a method to improve forest fire danger rating and a technique of vegetation fire behavior prediction using vegetation fuel maps (VF maps).
\end{abstract}

\section{Introduction}

Protected areas (PAs) are established to conserve biological diversity, to maintain nature complexes and objects in their natural condition. Taking into account the special regime and status of the environmental conservation institutions there, various IUCN categories of PAs are distinguished: strict nature reserves or wilderness areas (including biosphere ones), national parks, habitat/ species management areas, natural monuments, etc. Strict nature reserves prevail in Russia by their total area.

Large destructive fires are impermissible to develop in nature reserves and in natural monuments. This issue can be resolved largely by improvement of fire danger rating, fire behavior prediction and fire management. Vegetation fire management in nature reserves is quite possible on the basis of modern fundamental fire science developments which improve fire danger rating, prediction of an occurred fire depending upon weather

\footnotetext{
${ }^{*}$ Corresponding author: volokit@ksc.krasn.ru
} 
conditions, and make it possible to control flame (or flameless) combustion spread over the area and to take optimal decisions on fire suppression.

\section{Background}

Analysis of vegetation fires in Russian strict nature reserves was carried out by L.V. Kuleshov and V.N. Korotkov [1]. The dynamics of fires was analyzed by them for the period from 1975 to 2000 . They revealed a general trend of growth in the number of fires.

There are no special recommendations on fire protection at PAs in Russia. Until now, during their forest inventory, developments intended for forest management activities are used, for example, forest fire maps are created, in which categories of vegetation plots are divided into classes of natural fire danger [2]. This led to the fact that not only dry lichen pine forests, but in general all the debris-strewn areas (fire-damaged forests, dead-standing forests) and all coniferous young growth with any forest floor were included in the first class of the scale. And not only poorly burned sphagnum and long-moss pine forests, but also all grass forest types are classified as the fourth fire hazard class, although in spring and autumn in southern Siberia, fires in grass types with a predominance of grasses and sedges often turn into a natural disaster. In addition, there was no quantitative pyrological characteristics of areas included in one class.

Studies of quantitative criteria for the rate of drying to an ignitbale state in various categories of forest and non-forest areas in different regions were actively carried out in Russia in the 1960-1970s according to the methods of Professor N.P. Kurbatsky [3]. Scales of priority in ignition of plots were drawn up with an indication of the value of the forest fire drought index, at which plots of this category reach an ignitable state. But the total number of possible categories of plots in Russia is too large to cover all of them with research. Moreover, the forest floor of many forest types, identical in name, had large pyrological differences. It is almost impossible to study individually all this great variety of categories of plots. Their pyrological classification was necessary, the division of all forest floors into a number of pyrological types.

The analysis of published observations on drying of forest floors to an ignitable state, as well as special studies on the layer-by-layer drying of forest floors [4], allowed us to develop further the classification of forest fuels by N.P. Kurbatsky [5, 6]: in each fuel group we distinguished fuel types [7]. The division of the first fuel group (including mosses, lichens, and small plant residues) into types made it possible to show them on vegetation fuel maps (VF maps), the methods for creating which have now been developed. VF types of this group were named as the primary fire carriers (PFC) and their pyrological characteristics were obtained on the basis of many years of research on the moistening, drying and burning of various forest floors in different regions [7].

\section{Improvement of fire danger rating on PAs}

Among the fire hazard assessments used in forest fire practice for PAs, the most relevant is fire danger rating according to weather conditions and natural fire hazard assessment. The Sukachev Institute of Forest SB RAS developed methodological recommendations aimed at improving these types of fire danger rating. Thus, in order to improve the fire weather danger rating, it is proposed to use an improved index that takes into account the humidity and hygroscopicity of vegetation fuels and, unlike previous indices, "works" at negative temperatures. It is recommended to use this index in northern and central taiga areas with a predominance of moss and lichen in the forest floor, as well as in the Zabaikalie and Far 
East regions, where cured grass fires often occur in spring and autumn at below-zero temperatures $[8,9]$.

To improve the assessment of the natural fire hazard, it was proposed to use VF maps, the creation methods of which are based on the detailed VF classification [7]. To date, information databases have been compiled in GIS and VF maps have been made for a number of strict nature reserves: Stolby, Sayano-Shushensky, Kuznetsky Alatau, Ubsunurskaya hollow.

\section{Vegetation fire behaviour prediction on PAs}

VF maps also make it possible to predict the behavior of the fires that have occurred, since the maps contain the necessary pyrological characteristics of the vegetation. Under the behavior of a vegetation fire we imply the speed of its spread over the territory, the type of fire, its development (transition from a surface to crown or ground fire), as well as the immediate fire effects in the form of tree mortality, depending on the intensity of burning, the tree species and its average diameter [10]. Software programs for VF mapping and vegetation fire behavior prediction have been developed and patented, and they have been retrospectively verified and showed good performance $[11,12]$.

\section{Vegetation fire management on PAs}

To manage vegetation fires on PAs, first of all, it is necessary to create an information database containing VF maps. Since Russian PAs go through the first forest inventory type, it is quite possible to create the information database using the data of the previous forest inventory based on the technique developed by the Sukachev Institute of Forest SB RAS for analysis of forest type schemes and their pyrological characteristics. If old forest inventory data are not relevant already and a new forest inventory is being planned then it would be better to create a new information database for making VF maps with more accurate pyrological characteristics on the basis of the Sukachev Institute of Forest identifier for primary fire carriers in the process of forest inventory.

Further, on the basis of a chosen fire spread model, the developed computer software is used to predict behavior of a specific fire: specific pyrological characteristics are taken from the VF map as well as weather data on a given time. The software program calculates the surface fire edge spread in given time periods. On the sites where a surface fire can develop into a crown or a ground one, the program shows this probability. Besides, the software reflects possible fire effects in forest stands depending upon the combustion intensity, tree species and mean tree stand diameter in terms of tree mortality expressed in percent. Additionally, taking into account the length of a fire edge, the software calculates the necessary suppression forces for a given stage. By now, the vegetation fire behavior prediction software has successfully gone through a retrospective performance test in plain conditions (the Chunsky Forest Office of the Krasnoyarsky krai) and in mountain conditions (the Stolby Nature Reserve of the Krasnoyarsk krai).

\section{Conclusion}

Vegetation fire management is quite realistic on Pas of Russia. Most PAs have the necessary information database because their forest inventory is of a high forest inventory type. Nature reserves have their own weather stations and use automatic ones. The software for vegetation fire behavior prediction is pretty straightforward for the specialists of nature reserves to master. 
This paper is prepared under the support of the Russian Foundation of Fundamental Research grant № 18-05-00781A.

\section{References}

1. L.V. Kuleshova, V.N. Korotkov, Monitoring of communities on burnt areas and fire management in strict nature reserves (VNIIprirody, Moscow, 2002)

2. Collection of agency-level acts on forestry (Gosleskhoz, Moscow, 1979)

3. N.P. Kurbatsky, Methodical guidelines for practical development of local fire danger scales (TsNIILKh, Leningrad, 1954)

4. A.V. Volokitina, Lesovedenie, 1 (1985)

5. N.P. Kurbatsky, Methods and strategies of forest fire fighting (Goslesbumizdat, Moscow, 1962)

6. N.P. Kurbatsky, Forest fire science issues (ILiD SO RAN, Krasnoyarsk, 1970)

7. A.V. Volokitina, M.A. Sofronov, Vegetation fuel classification and mapping (SO RAN, Novosibirsk, 2002)

8. M.A. Sofronov, I.G. Goldammer, A.V. Volokitina, T.M. Sofronova, Wildland fire danger (IL SO RAN, Krasnoyarsk, 2005)

9. A.V. Volokitina, T.M. Sofronova, M.A. Korets, Improvement of fire danger rating in the forest (IL SO RAN, Krasnoyarsk, 2018)

10. A.V. Volokitina, M.A. Sofronov, M.A. Korets, T.M. Sofronova, I.A. Mikhailova, Forest fire behaviour prediction (IL SO RAN, Krasnoyarsk, 2010)

11. M.A. Korets, A.V. Volokitina, Software program for pyrological description of forest inventory plots (State patent № 2014660252, 2014)

12. M.A. Korets, A.V. Volokitina, Software program for surface fire spread prediction (State patent № 2015661771, 2015) 